\title{
Time, Politics and Homelessness in CONTEMPORARY JAPAN
}

\author{
Ritu Vij
}

Abstract

This paper examines heterotopias of homelessness in contemporary Japan. Against received claims about a shift from a social to a post-social form of politics, the paper draws attention to distinct temporal horizons that shape statist and precarious political subjectivities at sites of economic abandonment, complicating generalizations about the demise of the social and the shift to new (post-representational) political practices in neoliberal Japan. In contrast to the politics of representation that continue to mobilize statist social imaginaries around advocacy and care for the homeless, political heterotopias of homelessness index a critical refusal of hegemonic interpellations of home and home-coming. In an effort to expand understanding of the political in Japan, the paper draws attention to the multiple temporalities constitutive of the social space of homelessness. In so doing, it seeks to make visible fugitive forms of political subjectivities beyond statist and neoliberal enclosure, and contribute more broadly to a critical discourse on the nature of politics in contemporary Japan.

This paper examines heterotopias of homelessness in contemporary Japan. ${ }^{\mathrm{I}}$ Against received claims about a shift from social to 'post-social' forms of politics, the paper draws attention to distinct temporal horizons that shape statist and precarious political subjectivities at sites of economic abandonment, complicating generalizations about the demise of the social and the move to new (post-representational) political practices in neoliberal Japan. In contrast to the politics of representation that continue to mobilize statist social imaginaries around advocacy and care for the homeless, political heterotopias of homelessness voice a critical refusal of hegemonic interpellations of home and home-coming. In an effort to expand understanding of the political in Japan, the paper draws attention to the multiple temporalities constitutive of the social space of homelessness. In so doing, it seeks to make visible fugitive forms of political subjectivities beyond statist and neoliberal enclosure, and contribute more broadly to a critical discourse on the nature of politics in

I I am grateful to Reiko Gotoh and Paul Dumouchel for the invitation to give a Keynote address at a conference in Ritsumeikan University in $201 \mathrm{I}$ that provided the occasion for first developing a paper on 'Home and Homelessness in Japan.' My thanks also to Mustapha Kamal Pasha for careful reading and constructive critique of the argument pursued here. 
contemporary Japan. Marked by the demands of a life lived under conditions of radical contingency, the politics of the homeless (in contrast to the politics around homelessness) repudiate the very meanings of home, community, and belonging that stabilize the socio-political terrain of national and neoliberal imaginaries. Here, politics (as contestation) puts into question the very terms of inclusion that informs a politics around homelessness. Homelessness as heterotopic space offers an expanded understanding of the political field revealing the limits of dominant understandings of both national (statist) and cultural (neoliberal) forms of (de-politicized) politics and subjectivities shaped therein.

Between Dec. 3I 2008 and January 5, 2009, in a widely reported event, I700 volunteers led by the Zenkoku Komuniti Yunion Rengokai (National Federation of Community unions) created the Toshikoshi Hakenmura (New Year's Eve village for dispatched workers) in Hibiya Park in central Tokyo. Ministering to 500 unemployed and homeless workers - distributing food, organizing lodging, providing counselling on unemployment and welfare benefits - the heavily mediatised Hakenmura quickly assumed iconic status, its figuration of Japan's lost 15 years (ushinatta jugonen) from the early I990s to the mid 2000 signalling the irrevocable transformation of Japan from a predominantly middle-class (churyu) society to a kakusa shakai (divided society). As the Ministry of Health Labor and Welfare moved to open the doors of its building across the park to provide temporary shelter from the winter cold, and political parties across the spectrum expressed support for the workers, the unexpected return to national prominence of the politics of labor and 'social time,' at a point when Japan's seemingly total embrace of neoliberalism as a form of de-politicizing rule had, scholars suggested, all but foreclosed it, signalled a politics of hope with regard to the resuscitation of Japan's post-war egalitarian social compact. This return to a national social imaginary was later reinforced as Yukio Hatoyama, Japan's newly elected Prime Minister (and leader of the Democratic Party of Japan (DPJ) called for the renewal of ' $y u$-ai,' a national fraternity that ensures that the "perspectives of the disadvantaged in society and minorities are respected."3

On another register, however, the emergence of new political practices symptomatic of "representational disenchantment" (Mori 2005; Hayashi 20II) have solicited claims about a shift to a post-social mode of politics. Carnivalesque sound demonstrations, street parties, and art performances associated with the youth culture of freeter are seen as consolidating a new mode of political praxis in Japan, less concerned with 'collective action' and demands on the state (as

2 In accordance with the journal's policy, I have elected not to use macrons or circumflex for writing Nihongo (Japanese language) terms in Romaji (English) for purposes of this article.

3 Hatoyama Cabinet E-Mail Magazine No. 4, November 4, 2009. 
in the old left struggles of the 1960s), but rather, 'individual', expressive and cultural modes of political subjectivity. Thus anti-nuclear rallies in Hibiya Park in Tokyo in 2003, the 246 Artist meeting in 2007 against the expulsion of the homeless population at Shibuya railway station in Tokyo, the rally against the privatization of Shinjuku's Miyashita Koen (park) in 20IO, as well as ongoing protests in smaller forums (like the music-oriented digital commune Dommune and the Free Media Lab, for instance), are repeatedly invoked as inaugurating a new age of 'cultural protest' (Mori 2005) beyond the traditional domain of conservative or left politics of representation.

These new forms of political protest, expressive rather than collective reflect, scholars contend, the individualizing effects of neoliberal political technologies of governance. These include, off-shoring risk from the social state to the individual subject via the discourse of jiko sekinin (self-responsibility) in welfare and security policy (Hook and Hiroko 2007; Arai 2005), creating a "volunteering subjectivity" via the shaping of associational life or civil society (Ogawa 2009), within the domain of culture, a shift to the creation of "affective activism," a "fluid, mobile and detached subjectivity" better aligned with and productive of capital (Allison 2009), the replacement of a "politics of productivity" with a neoliberal "politics of consumption,"(Miura 2008; Iwabuchi 2008) and the emergence of a-social otaku (geek) practices of resistant subcultures (Azuma 2009). Coupled with the putative demise of 'maternal society' (bosei shakai) in recessionary Japan(Yoda 2000), these transformations of state and cultural practices have inaugurated, many contend, a post-social form of politics, rendering Hakenmura symptomatic of the return of a national social imaginary that is at best deemed anachronistic in the context of the neoliberalization of Japan. In this vein Hakenmura appears to name nostalgia for a time long past, and a politics of impossibility within a globally neoliberal dominant.

Seen from the vantage point of sites of economic abandonment ${ }^{4}$ in Japan, however, (the homeless, destitute, and chronically unemployed), the politics that materialize in what Michel Foucault describes as 'heterotopic social space's exceeds both the national and neoliberal enclosures of the political field. Heterotopias as 'counter-sites' materialize social practices and relationalities that 'represent, contest and invert' social order (Foucault [1967] 1984), enabling the

4 A growing literature on zones of economic abandonment under conditions of late liberalism has spurred a considerable theoretical and empirical literature on modes of survival by populations approximating Agamben's notion of 'bare life.' For particularly compelling discussions see Joao Biehl's (2005) Vita: Life in a Zone of Social Abandonment; Elizabeth Povinelli (201I) Economies of Abandonment; and Lauren Berlant (2011) Cruel Optimism.

5 The following section lays out in detail the political resonance of Foucault's notion of heterotopia and its relevance to imagining politics 'otherwise.' 
emergence of alternative modes of sociality that potentially reorder the political in distinctive ways. At heterotopic sites, the suspension of collective or social time manifest in socio-economic exclusion and marginality, much less the absence of a self-entrepreneurial temporal horizon, entails an understanding of the political that exceeds the temporal frames of both statist and neoliberal political forms.

Drawing on a theoretical framework that deploys Michel Foucault's analytic of heterotopia as a political supplement to Harry Harootunian's notion of 'coeval temporalities' that structure the everyday, this article seeks to contribute to an expansion of the political field in contemporary Japan. Insofar as both social and post-social forms of cultural politics work within temporal frames that reproduce the collective identity of what Kojin Karatani (2008) evocatively terms the 'capital-nation-state,' as the ground of political action around homelessness, they may be better seen as de-politicized forms of politics that fail to call into question the constitutive role of notions of home, property, and community in producing homelessness as a social pathology. In this context, when viewed from the vantage point of the materialities and social practices of homelessness itself, the heterotopic space constituted at the site of homelessness can be seen as delineating an alternative order of the political that emerges through the habitus, social relations and practices of the homeless. Specifically, the suspension of social time, in its developmental and neoliberal modes, at sites of economic abandonment shapes social relations and subjectivities that ground an alternative imagining of politics, one that makes visible the limits of political imaginaries (of the right and the left) already materialized. Insofar as homelessness invites a different scopic regime ${ }^{6}$ to denaturalize standard understandings of the political, its discussion here may prove illuminating. In focussing on homelessness as one such site of contestation as an alternative political imaginary, this article attempts to contribute to a critical understanding of the nature of politics and political order beyond its current statist or neoliberal framings in the context of Japan.

The discussion is organized in three sections. The first outlines the context within which homelessness in Japan is produced as a sociological, rather than political problem, soliciting a politics around homelessness that reproduces either a statist social narrative (of rescue, care, and protection), or performa-

6 For some scholars, the scale of the problem of homelessness in Japan - 30,000 'visible homeless,' relatively small when compared to that of the United States or the United Kingdom, may be seen as too small to carry the weight of the argument pursued here. It is, however, precisely in considering homelessness as heterotopic site that its significance to understanding the question of the political in Japan gains salience. 
tively enacts a politics of 'representational disenchantment' (Hayashi 20II) that nonetheless fails to interrogate collective identity as the ground for political action. The second makes a theoretical case for deploying 'heterotopia' as a heuristic device for analysing the politics of space-time as constituted within the site of homelessness in Japan. The third offers an analysis of the political heterotopias of homelessness in Japan that unsettles received understandings of home and home-coming and the political subjectivities temporalized to these ends.

\section{Homelessness as 'Social Pathology' in Japan}

Japan's passage from a developmental state to a neoliberal one since the late I980s is usually attributed to the Liberal Democratic Party's aggressive pursuit of de-regulation (kisei kanwa), privatization (minkatsu) and marketism (shijoshugi), in keeping with the compulsions of the 'Washington Consensus'. The concurrent rise in the numbers of economically displaced since the bursting of the economic bubble in 1991 has generated a sustained social and economic malaise, variously indexed by the new categories of social classification used to disaggregate the population of late capitalist Japan - furita (flexible part-time employed between I5-34 years of age), hikikomori (chronically self isolated individuals), NEETS (neither in education, employment or training), and waakingu pua (working poor). The creation of the 'new homeless,' more than one-third of the work force in irregular employment, and an unprecedented (5.4\%) unemployment rate (in 2002) (Genda 2007) has put to rest claims about Japan's developmental state's 'magical' prowess in sustaining the economic miracle of the I980s, with the 'precariat'8 rather than the sarariman increasingly figuring as the central motif of late capitalism in Japan. Japan's soaring poverty rate ( $\mathrm{I} 6 \%$ in 2009 , or 20 million \{one in six\} Japanese in poverty), 9 etches Japan's economic decline in stark terms: Japan's poverty rate, measured as less

7 A portmanteau combining the words 'free' and the German arbeiter for part-timer.

8 A neologism combining the terms 'precarious' and 'proletariat', the precariat as become the centrepiece of a growing literature on insecure labor in the advanced industrialized countries. Amamiya Karin, a onetime rock star turned activist and Makoto Yuasa are among the most widely recognized figures of the precariat in Japan. For discussions of precarity in Japan see Allison 20I2; Amamiya 2007; Miyazaki 2006; Yuasa 2008.

9 The Japan Times Online, 20II. Poverty Rate Hit Record High in 'o9. Japan Times Online, July I3. Also see OECD FactBook Statistics 20II-20I2. http://www.oecd-ilibrary.org/economics/oecd-factbook-2OII-2OI2-factbook-20II-en 
than half of mean average income, is the $2^{\text {nd }}$ highest (after the United States) among OECD countries (Tachibanaki 2008).

In this context, the discursive rise of homelessness as a new social problem, evident in the growing use of the term homuresu in the I990s typically reserved for signifying homelessness in the West rather than the more traditional furosha (vagabond) used in the domestic context, is notable for its elision of a prior suppressed history of poverty and homelessness in Japan. Day labouring districts in San'ya (Tokyo), Kotobuki in Yokohama, Kamagasaki (Osaka) populated by a transient, predominantly male population, with weak or non- existent family ties were a long standing feature of 'miracle Japan.' Resistant to the salary man culture of rigid social and communal hierarchies and obligations, day labourers in yoseba (day-labour market) in the heyday of the Japanese miracle economy enjoyed a relatively secure material existence due to the construction boom sustained by a buoyant construction state.

With the bursting of the economic bubble in the early 1990s, however, the rapid increase of the numbers of homeless (16,000 in 1998, 24,000 in $200 \mathrm{I}$ and around 30,000 today $)^{10}$, has brought the problem of homelessness into greater visibility as cardboard or vinyl covered makeshift shacks have mushroomed in public parks in cities like Tokyo and Osaka. Within a burgeoning sociological literature ${ }^{\mathrm{II}}$, structural reasons are largely cited as the predominant cause of a rising instance of homelessness including the following: unemployment during the Heisei recession; disemployment of casually employed unskilled workers; the reorganization of the sub-contracting systems in the construction industry and above all 'deyosebisation' (the collapse of the day-labor market), in the aftermath of the end of doken kokka (construction state). Yoseba as a clearing house for temporary workers in the steel, shipbuilding, coal industries or construction work in the 1980 os have increasingly become hubs for homeless men, as gentrification of low income housing or doya-gai in places like Tokyo and Osaka have rendered those in precarious work homeless. Access to public welfare subsidies are subject to strict eligibility criteria, the koseki (registration of origin) and a residence card, impossible for a mobile population lacking a residential address, rendering the homeless largely without any recourse to public assistance. ${ }^{12}$ A largely male population over 50 years of age who have

IO Koseirodosho 2006. Ministry of Health, Labor and Welfare, White Paper.

II For particularly good sociological accounts of homelessness in Japan in what is now a rapidly expanding area of scholarship, see the following: Aoki 2003; Dvorak 2003; Fowler 1996; Gill 200I; Guzewicz 1996, 2000; Iwata 20I0; Kennett and Iwata 2003; Mizuuchi 2003.

I2 The 2002 Special Law on Temporary Measures to Support the Self-Reliance of Homeless People (Homuresu no Jiritsu jino Shien nado ni kan suru Tokubetsu Sochi-ho) introduced some flexibility in allowing certain shelters to be recognized as residences, making it easier to claim 
no place to live(Iwata 20Io), those seeking shelter through welfare centers offer a sharp contrast to the early I990s when most people arriving at shelters only needed temporary housing on release from hospital. Many work crushing aluminium cans for delivery to recycling centers that earns the men some spending money, ${ }^{13}$ others earn a fraction of the price for every copy of the Big Issue Magazine ${ }^{\mathrm{I}}$ they are able to sell at street corners and traffic lights. Finally, unlike other advanced industrialized countries where the homeless population includes women and children, in Japan, women in extreme poverty do not typically become 'rough sleepers' due to a policy framework that, recognizing the significance of mothering, has programmes in place to provide shelter and support (hospitals for instance) for homeless women with children.

It is striking, however, to note that in Japan, unlike countries in Europe and North America where the category of homelessness includes those in unstable housing or those living temporarily with friends and relatives, the much more stringent approach used in Japan counts only 'rough sleepers' as homeless. The New Homeless Law (2002) defines homeless as those "who illegally live and lead daily lives in such facilities as city parks, riversides, roads, railway stations etc." ${ }^{15}$ Analogous to the political ${ }^{16}$ rather than merely sociological construction of homelessness elsewhere (racialized in the US for instance, or construed as a problem limited to indigenous populations in Australia), the delimitation of the problem of homelessness to that of rough sleeper in Japan, narrows the

living expenses by homeless individuals.

I3 With one of the highest rates of recycling aluminium cans (90\%) among OECD countries, homeless men could earn up to 4000 yen a day for 20,000 cans delivered to recycling centers across Japan. With the 2008 financial crisis, however, and the global economic slowdown, the price of aluminium cans has fallen sharply with earnings now down from 4000 to 1600 yen a day. In Sumida ward of Tokyo, a new law in October 2010 made it illegal for anyone except authorized agents to remove recyclables (comic books, magazines etc.) left at designated refuse sites, denying the homeless access to what used to be a means of earning some money. Since then 13 of Tokyo's 23 wards have implemented similar regulations, as well as cities such as Chiba and Sapporo (Brasor and Tsubuku 20I0).

I4 Big Issue, a UK based charity promoting self employment by homeless people through the sale of the Big Issue magazine opened in Osaka, Japan in 2003. Since 2004, a Japanese football team dubbed 'Nobushi' (independent samurai) has been participating in the Homeless World Cup organized by the Big Issue charity annually in different countries.

I5 The 1995 Tokyo Metropolitan Government's Report on the homeless problem uses the term rojo-seikatsusha that means 'people who live on the street.' Daily workers who are rough sleepers are termed nojukusha.

I6 The shift to a political rather than merely sociological understanding of the production of homelessness as a category has generated a constitutive approach to the problem of homelessness. See for instance, Leonard Feldman (2004) Citizens Without Shelter, Kathleen Arnold (2004) Homelessness, Citizenship and Identity. 
mondai ishiki (problem consciousness) of homelessness such that it brings into visibility only a partial or distorted image of the problem, one that succeeds in rendering the 'problem' of homelessness in alignment with a normative understanding of collective identity as the precondition for political action. A politics around homelessness then, devoted to bringing in the marginal or the excluded (rough sleepers in this case) into normalized sociality (as elaborated below), forecloses interrogation of the very distinctions that produce the problem in the first instance. Thus, the politics of rescue and care around homelessness, insofar as it takes as its focus the visible homeless (Hakenmura being a case in point) fails not only to bring into visibility the invisible homeless, (those living in temporary housing or kakurega (refuges, as further discussed below), but also fails to disturb or disrupt the categories that stabilize the socio-political field, thereby de-politicizing the question of homelessness and its intimate connections to normative notions of home, community, and belonging in Japan's 'capital-nation-state' as constitutive of homelessness itself.

Thus, the trope of mai homu shugi (also known as 'mai homeism,' a 'desiring subjectivity' shaped by the regulative ideal of owning and being in 'my home'), that mobilized a family and corporate centered social compact in post-war Japan, effectively sutured labour to the dream of private home ownership. ${ }^{17}$ As many have remarked, the gendered dimensions of the heteronormative constellation of family-kaisha (company)-state around which social relations of ibasho (belonging) were shaped in the heyday of Japan's economic miracle, effectively rendered the loss of 'home' disruptive of the normative architecture of postwar Japan's 'family corporate system' as a whole. Incentives provided by the Government Housing Loan Corporation (GHLC), for instance, targeted the growth of middle class home ownership, with comparatively little assistance for increasing the provision of private rental housing, or low-income housing. Despite its characterization as doken kokka (construction state), in other words, the state's explicit policy of channelling its spending to infrastructural projects (roads, highways, bridges etc.) leaving the provision of housing almost exclusively to the private sector is key to understanding the lack of housing diversity in Japan. The low level of public rental housing (around $7 \%$ ), the

I7 Jordan Sand's (2003) careful analysis of the emergence of notions of a 'proper family-centered dwelling' of the middle ranks (churyu) in Japanese cities in late Meiji and early Taisho eras can be read as symptomatic of the wider dispersion of this norm in 'miracle Japan'. As notions of home increasingly reflected bourgeois constructions of domesticity, private property, and culture, the narrowing of notions of the home can be seen as constitutive of the idea of homelessness as the absence of a 'proper home,' requiring no more than minimum shelterization through an ethics of compassion and care. 
absence of a policy to develop low income housing, ${ }^{18}$ and the gentrification of housing traditionally available to day labourers (doya) in areas has contributed significantly to the phenomenon of 'rough-sleeping' in Japan ${ }^{19}$. Insofar as home ownership actively promoted in post-war Japan's 'homeowner society ${ }^{20}$ as a means of limiting welfare provision for the elderly (Hirayama 2010), remains central to Japan's social imaginary (seen for instance in the widely popular television series, Freeter, Ie o Kau (Freeter Buys a House), ${ }^{2 \mathrm{I}}$ a beleaguered economy notwithstanding, the de-politicized nature of an activist politics around the rescue of 'the homeless' can be clearly seen as located in a statist narrative of futurity and hope.

Continuities with a statist social imaginary of bosei shakai (maternal society) are also evident, for example, in the invisibility of women in homelessness. Due to an existent policy framework that allows women with children to be housed in hospitals or shelters, the ideal of a matri-centric domesticity attached to normative notions of home, and its deep imbrications with 'capital-nationstate' can be preserved. Since fear of abuse and violence keeps women without recourse to shelter off the streets, women without shelter fall off the radar of a politics of compassion around homelessness. ${ }^{22}$

Then there is the growing phenomena of refugees, those living in kakurega

I8 A survey conducted by the newspaper Asahi Shimbun in Japan's 47 prefectures and I9 major cities in 2010 found that one third of those polled had reduced the number of units of low income housing in the future due to a 'declining population' despite the fact that demand for low income housing as increased due to the prolonged economic recession. There are 9.9 applicants for every unit of low-income housing, which contributes in no small measure to those unable to find affordable housing living on the streets. See http://catforehead.wordpress.com/20I0/I2/o8/publichousing-on-the-ropes/ (accessed 5 September 20I2).

I9 Leonard Feldman (2004) notes, in the context of the United States, how a similar emphasis on home ownership led to the closure of residential hotels which housed single, often low-income individuals, thereby reducing housing diversity which in turn made it more likely that those without access to normatively constructed notions of home (the detached single family home) would end up 'homeless' rough-sleepers.

20 Hasegawa (2006) points out that of the 300 ,000 relief housing units the postwar government was committed to developing in 1945 to accommodate the more than 400 , 000 households displaced by the war, only 81,000 had been built by 1946 .

2I By contrast, Homuresu chugakusei (Homeless Junior High School Student) a transmedia phenomenon that was made into a television drama, manga, a film and children's books offers a redemptive story of endurance and hope, individualizing homelessness in the figure of youth, and reactivating familial tropes of belonging and sociality. See Alisa Freedman (2011).

22 In 2008, a homeless 58 year old woman, Tatsuko Horikawa was found hiding in the closet of a Fukuoka man. She had lived undetected in his closet for a year, raising suspicion only when the regular disappearance of food from his kitchen led the man to install security cameras in his apartment (The Japan Times 3I May 2008). 
(dormitories, cheap hostels (doya) comprising a much younger demographic of part time employees (freeters), who lacking adequate income or long term stable employment have taken to sleeping in 24 hour spots such as Mcdonald's restaurants or internet cafés that enable access to showers, food, the internet, and a place to sleep, at affordable rates. ${ }^{23}$ Termed the 'hidden homeless' by the media, insofar as they do not reproduce the standard imagery of the visible homeless, "neatly dressed and carrying mobile phones, sometimes PCs and portable music devices as well" (Yoshida 20I2) there were some 5,400 'Net Café Refugees,' McRefugees, or cyber homeless dennou furosha) in mid-2007. Documentary films such as Mizushima Hiroshi's Net Café Refugee and Net Café Refugee The Poor Floating around in the City (made by Nihon TV) has drawn wide media attention and publicity but contributed, critics suggest, to creating a "sense of discrimination against the hidden homeless."

In this context, voluntary efforts ${ }^{24}$ geared toward ameliorating the condition of the visible homeless through the combined provision of soup kitchens, faith-based initiatives that run night patrols in Osaka ${ }^{25}$ in the winter months distributing blankets and food, providing temporary shelter to those most frail and unwell, or large scale events like Hakenmura and the sound demonstrations protesting the plight of rough-sleepers, act as supplement to the socioeconomic disparities of wealth and want in contemporary Japan. Expressing

23 According to estimates by the Ministry of Health, Labor and Welfare, 2007, there are about 60,000 people who fall into this category of 'net refugees' which includes two cohorts of people, mostly young people in their 20 - part time workers lacking access to stable accommodation, or those over 50.

24 Voluntary organizations seeking to ameliorate the plight of the homeless or advocate on their behalf are usually Christian faith-based organizations. Among the more widely known that target homelessness specifically are Hurusato no kai in Tokyo, and Kitakyshu Homeless Assistance Organization. In Osaka, with the largest number of homeless men, the Rengo Osaka, the Buraku Liberation League Osaka, and the Kinki Lawyers Association are especially well known. Most NPOs involved in the assistance of homeless people, however, focus on identifying cheap rental accommodation, and negotiating contracts on behalf of those homeless who have managed to secure livelihood protection assistance from the government. In areas with dense homeless populations like Shinjuku, Shibuya, Ikebukuro in western Tokyo, San'ya in Yokohama and Kamagasaki in the Airin district in Osaka, efforts of NPOs are largely geared to sociological rather than political ends. In places, the homeless too have founded organizations of their own like the Homeless Network and Osaka Jo Tomo no Kai (Friendly Association of Osaka Castle Park).

25 'Second Harvest' runs the largest food bank in Japan, collecting cans, vegetables and cooking materials from supermarkets, cooking and distributing meals with the help of a large number of volunteers. I worked as a volunteer several Saturdays in 2005, distributing food to long lines of people in Ueno Park in Tokyo, and was also able to take part in a night patrol in Kamagasaki, Osaka in 2003, while teaching at Ritsumeikan Daigaku in Kyoto. 
either a humanitarian ethos of charity or solidarity with those marginalized and excluded from socio-economic norms, both social and post-social forms of politics around homelessness work within the limits of a political imaginary that takes as its telos, the time of the nation (Japan) and the time of capital (development). The rise of a new niche market for "poverty business" (a term coined by the social reformer Makoto Yuasa) referring to the extraction of a margin of the housing and livelihood protection fee of livelihood protection recipients, speaks to the seamless production of both advocacy and protection for the homeless and the socio-economic terrain of capital within which it is located. Working within the temporal parameters of a developmental logic, specifically the utopic promise of economic progress contained within practices of rescue and care, advocacy on behalf of the homeless may appear depoliticizing insofar as it mobilizes a collective identitarian horizon of a shared or normative sociality. Anticipating the discussion that follows in the next section, this advocacy for the homeless may be seen as an instance of what Foucault calls "an inversion of the temporal axis of the [political] demand," the right of the homeless to shelter "is articulated in terms of a potentiality, a future... which is already present in the present because it concerns a certain function of Statist universality that is already fulfilled by a nation within the social body, and which is therefore demanding that its status as a single nation must be effectively recognized and recognized in the juridical form of the State" (Foucault 1976, 222).

As the economic marginalized and dispossessed are folded back into extant modes of sociality and belonging with social and post-social forms of politics centered on the provision of 'shelter, ${ }^{26}$ the normativity of the socio-political landscape constitutive of homelessness in the first instance is reinscribed rather than repudiated. Echoing rather than contesting the modes of sociality and material practices shaped within the collective time of the nation-state, in its developmental or neoliberal moments, the politics around homelessness may be better understood as de-politicized praxis that augments rather than ruptures the current socio-economic-political order in contemporary Japan. The de-politicization of the problem and politics of homelessness in other words, is

26 The claim that the homeless are deserving simply of minimal 'shelter' - a warm blanket, a mat to sleep on in temporary accommodation - and as such are emblematic of 'bare life' whose exclusion from the proper citizenship is in fact constitutive of it, circulates widely in the critical literature on homelessness. While 'shelterization' as a matter of practical politics in the first instance, may well be justified, the central point for my purposes here is that to the extent the politics of homelessness is exhausted by 'shelterization' per se, it forecloses a properly political (i.e. contestation) about the categories (of home and homelessness, inclusion and exclusion etc.) constitutive of homelessness as a political, not sociological condition. 
shaped by a temporal frame that reproduces rather than interrogates a spatiality that remains fundamentally national/collective.

In the section that follows, I briefly outline a theoretical framework that enables a recuperation of a politics of contestation at the site of homelessness that is pursued in section three below. I briefly track discussions of the politics of space-time that bear on the specificity of Japan's contemporary conjuncture.

\section{Temporality, Subjectivity, Politics}

In an influential essay on the politics of space-time, Doreen Massey (1992) makes a persuasive case for complicating binary framings of space and time that have inadvertently accompanied the spatial turn in critical social theory. Against historicist narratives of temporally constructed hierarchies between spaces, Massey's critique of claims of coeval spatialities that empty space of time, inadvertently de-politicizing space, carries particular resonance in the case of Japan. Shmuel Eisenstadt's (1996; 2002) influential reading of Japan's non-axial civilizational singularity, heavily oriented to "strongly vertical, particularistic modes" (Eisenstadt 1996,IO2) in which the cultural program of modernity, institutional changes notwithstanding, remains strongly oriented to the reproduction of the collectivity, virtually empties Japanese space of time. For Eisenstadt, the timelessness of the ever present 'dominant' of vertical particularistic modes of being offers an account of Japan's distinctive modernity. Antinomies produced by the introduction of discordant capitalist temporalities (linear as opposed to cyclical), are by definition subsumed to its logic, rendering the site of politics, at the limit, de-politicized, (i.e. inherently bereft of contestation). On this view then, the politics around homelessness whether social or post-social insofar as it reproduces the collectivity as its object and telos, may be rightly seen as de-politicized, as I have also argued above.

Against this notion of the timelessness of 'Japanese' space, ${ }^{27}$ Harry Harootunian's work on 'coeval temporalities' and its role in structuring everyday life in modern Japan uncovers the workings of a 'temporal mix.' Arguing, (with

27 Considerations of 'Japanese' notions of time as time needed to reproduce the 'social' in distinction to capitalist (mechanical, clock) time have also been taken up by scholars more interested in accounting for the sociological effects of time in contemporary Japan. See for instance, Steger 2006; Tsuji 2006; Hasegawa, 200I. For a discussion of the temporal complexities that shape encounters with the immigrant in Japan, see also Vij 2012. 
Koselleck) that "everything has the measure of its own time," (Harootunian $2005,25)$, the temporal fixity of the collectivity emphasized by Eisenstadt is punctuated by the antithetical cyclical temporality of nature, one that brings "older practices, residual mentalities," non contemporaneous but coeval with capitalist clock time. For Harootunian, the site for the production of this noncontemporaneous contemporaneity is the everyday, encompassing "material culture, gestures of labor and desire, mechanical movements both human and properly mechanic." ${ }^{28}$ Here, within the everyday, the time of the nation and the time of capital may be effectively 'resisted' opening up a space for contestation that Eisenstadt's framework effectively forecloses.

Harootunian's emphasis on directing analytical attention to the production of space within the context of the antinomies contained within the temporal mix that obtains at the level of the everyday, gestures towards an understanding of politics that is necessarily contingent, unstable, and subject to contestation. On this account then, the (re) production of the time and space of the 'social' (nation-state) entails an ongoing negotiation/contestation with the practices and mentalities of other times and spaces that remain co-present: modern subjectivity in other words is structured by this (temporally constituted) tension. Neither claims about the necessary (because logically prior) continuity of a politics oriented to the social collectivity, nor those about a shift from social to post-social politics (induced by a new (neoliberal) modality of capitalism, can be sustained on this view. The subject, in other words, is never either fully enclosed by the 'diagram' of constituted (capitalist) social order, nor wholly the bearer of pre-modern/capitalist cultural sensibilities, but rather the bearer of polyrythmic sensibilities and mentalities whose political praxis bears witness to this temporal multiplicity. The asymmetries produced by differing and coexisting temporalities within the everyday, in other words, include not only the spectres of the past (pre-modern, cultural forms of 'other' ways of being) but also, and this is my point here, the measure of time produced by antecedent forms of state action that themselves live on, and which are never fully evacuated with changes in the state's effort to re (produce) subjects better aligned to the times and demands of capital.

As such, neo-Foucaultian claims about the shift from strategies of rule of the 'social' to a post-social form of self regulation that inaugurates the 'death of the social' (Rose 1996) elide the question of the 'temporal matrix' within which subjects are constituted. Foucault's description of 'disciplinary society' as a form of social government, in which the "production of docility" (in 
schools, prisons, hospitals, and military barracks, and the capitalist wage system) through "technologies of temporalization" (Binkley 2009, 72) draws attention to 'duration' as a temporal frame, such that the outcome of an action , the risks it entails - were bound not to the individual but to the collectivity, or "the institutional totality within which it [was] is excecuted." The Keynesian welfare state, or given our present concern, the Japanese 'developmental state' (Johnson 1982) might thus be seen from this vantage point, as a form of social government in which 'durational time' provided "a mechanism of social integration... wherein risk is socialized and the agency of individuals is transposed from the horizons of individual actions to those of institutional norms" (Binkley 2009, 73). The shift to neo-liberal forms of governmentality that take as their object the creation of self-regulating subjects better attuned to developing forms of market agency (autonomy, self-interest, entrepreneurial risk taking), thus depends fundamentally on the creation of new temporal horizons in the inner life of the neoliberal subject, overcoming the "residual social temporalities that persist as a trace in the dispositions of neoliberal subjects" (Binkley 2009, 60). This 'overcoming' is neither automatic nor instantaneous, a matter of immediate 'internalization' of neoliberal policies, but entails divergent and uneven measures of time in different societies, given the temporal asymmetries that structure the everyday as discussed above. That is, claims of a shift from social to post-social forms of politics are likely to be over-drawn as indeed some theorists have begun to categorically recognize. ${ }^{29}$

Tempering the analytical over-reach of neo-Foucaultian claims of neoliberal governmentality and its erasure of practices of dissent or resistance based on an irreversal shift in the temporal horizons of liberal and neoliberal technologies of rule, it is, however, Foucault's notion of 'heterotopia' ${ }^{30}$ that paradoxically offers a potentially productive political supplement to Harootunian's notion of the temporal mix contained within capitalist modernity, allowing for a better understanding of the tenor, possibilities and limits of politics today. I turn now to a brief elaboration of heterotopia as a political counter-site, before deploying it in the context of homelessness in Japan in the rest of the paper.

In 'Of Other Spaces' [1967] (1984) Foucault suggests that unlike utopia the non place of society in perfected form, there are "...in every civilisation, real places - places that do exist and that are formed in the very founding of society - which are something like counter-sites, a kindly of effectively enacted

29 See especially Povinelli 20II, and Berlant 20II.

30 There is a substantial interdisciplinary literature on Foucault's notion of heterotopia. See in particular Dehaene and De Cauter 2008; Genocchio 1995; Hetherington 1997; Saldanha 2008; Soja 1995; Watson and Gibson 1995. 
utopia in which the real sites, all the other sites that can be found within the culture, are simultaneously represented, contested, and inverted" (Foucault [1967] 1984, 24). Key to this understanding of heterotopia as a place of Otherness, unsettling of spatial and social relations is, for Foucault, the suspension of traditional or 'collective time' such that the materialities and social practices that take shape in heterotopic space order the social in ways that are distinctive. Rather than see heterotpia as intrinsic, Foucault's insistence that it is through similitude (rather than resemblance or representation) that the heterogeneity of materialities and social practices contained within heterotopic space constitutes a 'bricolage effect' that has an unsettling, disturbing effect, is particularly instructive in the effort here to recuperate the 'political mix' that obtains in the context of coeval temporalities. If statist/capital collective time, in other words, is punctured by feudal traditional time (Harootunian) in the realm of the everyday, the representation, contestation and inversion of social time in heterotopic counter-sites offers an alternative ordering of the political (Hetherington 1997).

Although concerned more with showing how textual discourse is unsettled by modes of heterotopic writing that do not follow expected rules and conventions, the widely influential conceptual deployment of heterotopia in urban studies for instance, demonstrating the disordering of public space by countersites is indicative of the productive use of the heterotopia as a heuristic. To the extent that heterotopic spaces turn back on 'collective time,' they demarcate a temporally distinct form of sociality, one whose representation, contestation and inversion of other sites (and times) can be seen as a form of contestation that calls into question the terms of an already constituted political field. I turn now to an analysis of homelessness as heterotopic space in contemporary Japan, to show how an alternative ordering of the political at the site of homelessness helps to expand the political field in contemporary Japan beyond statist or neoliberal enclosures of politics in current discourse.

\section{Homelessness as Heterotopia}

Within conventional thought, a progressive identity based politics seeks to bring into the field of representation those excluded or marginal to it. The politics of compassion comprising both advocacy on behalf of the homeless as well as expressions of solidarity with the homeless as discussed above are a case in point. Here sociological determinations of a group - 'the homeless' - as ex- 
cluded (from housing and food security, employment for instance), motivates a politics of inclusion into an extant sociological field, entailing neither interrogation, rupture, or de-classification of the sociological terrain itself. In keeping with an alternative understanding of politics, however, a properly political project entails contestation, the troubling of boundaries sedimented within the socio- normative field productive of the problem in the first instance, to enable new modes of being and social relationalities to emerge. Foucault's understanding of heterotopia offers one such crystallization of a political moment in which the creation of disjunctures or fissures within normatively defined identities or categories unsettle conventional sociological modes of analysis, enabling an alternative sociality to emerge. If political activism around homelessness depoliticizes homelessness as a sociologically determined category, homelessness viewed as a heterotopic site enables an alternative thought of the political ${ }^{31}$ that eschews normatively given notions of home and the regulative ideals that structure the socio-political field constitutive of it. Repudiating an ethics of liberal empathy contained in social and post-social forms of politics around homelessness then, I turn now to outlining some of the ways homelessness as a site of economic abandonment offers an alternative register of the political. Contra romanticization of the homeless (as a marginal or excluded group), the discussion that follows offers instead a counter-narrative to claims of pity or repellance that drive the politics around homelessness discussed above.

Across the major cities of Japan, under bridges, at train stations, public buildings and parks, the blue tarp coloured shelters and cardboard boxes that house the homeless, Japan's constitutional guarantee of a 'minimum standard of living' to all citizens (Article $25^{32}$ ) notwithstanding, have become an all too familiar sight. Periodically covered by the media as instances of violence against elderly homeless men steadily increase (Aoki 2003), representations of the homeless offer a fraught mix of pity and contempt. While a small percentage $(20 \%)$ construe the problem of homelessness as a 'social issue' warranting

3I I am not suggesting here that homelessness offers a model of 'practical politics' that can be readily mobilized to overcome the limits of statist and neoliberal forms of social and post-social politics. Rather, my point is to show how heterotopic sites enable an 'other' thinking that moves the question of politics and its ends beyond the question of mere inclusion, to interrogate and re-think the inequities and hierarchies constitutive of social order. Insofar as the work of revealing the violence of 'social time' in other words is enabled by the deployment of Foucault's notion of heterotopia as re-imagining/re-ordering, it offers a potentially productive response to the noted political theorist R.B.J. Walker observation (I998) that the "the most challenging political problems of our time arise from a need to re-imagine what we mean by politics" (Walker, 1998).

32 The Constitution of Japan, Article 25. http://www.kantei.go.jp/foreign/constitution_and_ government_of_japan_constitution_e.html. 
the extension of social empathy and care to the homeless, for a large majority the homeless 'have come to be regarded as an eyesore by pedestrians and neighbouring residents and often are violently harassed by them" Aoki notes (2003, 364 ), drawing attention to the high numbers of the public inclined to see the issue of homelessness in terms of "civic beauty and annoyance at the abuse of public spaces." ${ }^{33}$ Violent clashes between police and the homeless (most notably in Kamagasaki in 1990 and 2008$)^{34}$ reinforce the random violence directed against the homeless by bored youth.

The violence directed against the homeless stands in sharp contrast to the general absence of violence within neighbourhoods and parks where the homeless dwell. Unlike the skid rows or homeless ghettos of New York and Los Angeles for instance, where access to drugs and guns coupled with high rates of alcoholism produces a general climate of danger, walking alone around the streets of Kamagasaki in Japan's biggest homeless 'ghetto' raises little cause for alarm, either for social workers or gaijin (foreign) researchers. ${ }^{35}$ This absence of violence at the site of homelessness in contrast to the violence directed against the homeless is especially instructive in understanding Foucault's claim that heterotopic sites, insofar as they occasion temporal dislocation, function as 'counter-sites' of social order. This temporal dislocation consists in the suspension of 'social time.'

The suspension of social time at the site of homelessness erases the distinctions and the forms of violence attendant on the boundary making practices that flow from it, rendering the site of homelessness itself (because subject to an Other temporal frame), safe. In contrast, the violence directed against the homeless is anchored in modes of being shaped by social time, in which

33 Aoki 2003, 364 .

34 Kamagasaki in the Airin district of Osaka has a long history of riots by day-laborers and homeless people, beginning with the famous riot of 196I. The riot against police brutality against a defenceless elderly homeless man in 1990 brought thousands out in protests over a period of several days, 'justifying,' the government claimed, the use of riot squads against a highly vulnerable population. On 13 June 2008, against the backdrop of the upcoming G8 Summit, an act of police brutality against a homeless man resulted in riots in Kamagasaki, galvanising the removal of all homeless people from public spaces (including bus terminals) in Sapporo, Hokkaido where the G8 Summit was to be held a month later.

35 I first conducted research in the Kamagaski region of the Airin district in Osaka in 2005, as a recipient of a grant from the Social Science Research Council (USA) and the Japan Society for the Promotion of Science (JSPS). Since then, I have periodically returned to Kamagasaki to document changes on the ground, interview social workers, NPO representatives, and some of the homeless occupants of the Welfare Office Building. In the summer of 2008 and 20Io, with the support of the Carnegie Trust of Scotland, I was able to re-visit Kamagasaki to conduct field work. 
the normativity attached to specific modes of being (home owners, citizens, occupants of public space) depends on a framing of some modes of being as 'other' (non-citizen, homeless, and public disorder), thereby warranting the violence unleashed against these 'disposable' others. Foucault's crucial insight about heterotopias as the suspension of social time thus drives the discussion of alternative - heterotopic - framings of community, belonging, work and property at the site of homelessness that follow.

Inverting normatively given notions of house and home, the cardboard structures stitched together with rope and clips, reinforced with plastic and tarpaulin along Sumida-gawa and Tama-gawa in Tokyo as well as large parks Yoyogi, Hibiya, Ueno in Tokyo and Nagai in Osaka, draw attention to modes of dwelling (as opposed to housing) as an alternative site of sociality. Using the sides of buildings, windows and pillars under bridges as 'walls' and recycled refuse to build shelters that can withstand the rain and snow, albeit poorly, and discarded cooking utensils and stoves, in some cases, books, candles, tables and chairs, these homes function as what the musician/architect Kyohei Sakaguchi has evocatively referred to as 'Zero Yen Houses' made from "materials that others throw away: construction site waste, disused car batteries, and solar cells that produce just enough electricity to power a stove or a television. ${ }^{36}$ Increasingly the object of documentation by a growing number of international photojournalists, the 'meticulously planned huts and shacks' are viewed, for instance by Ari Saarto in his project 'In Situ,' as creative dwelling places, rather than abject zones housing the 'bare life' of 'disposable' workers (Shiho Fukada) ${ }^{37}$. Viewed from the outside, the blue tent villages in Yoyogi, with their recycling bins, shoes placed neatly outside tents (so as not to bring in the dust and grime outside (soto) indoors (uchi) calls to mind the conventions

36 From the write up for 'Zero Publics- Practice for Revolution, an exhibition of Sakaguchi's work at the Haus der Berliner Festspiele, 27 September 20I2. Available online at http:// www.berlinerfestspiele.de/en/aktuell/festivals/foreign_affairs/program_fa/pro. (Accessed I7 October, 20I2). Sakaguchi, a student of architecture at Waseda University describes seeing a house built by a 'homeless' man living by the Tama River in 2000. The house made entirely from things found lying on the ground had a total building cost of zero yen. He also makes note of the Solar Zero yen House, built by the Sumida river near Asakusa, Tokyo, in which a \$90 solar panel bought from Akihabara (the electronics district in Tokyo) was used to power a radio, television, and lights in the house. See 'Kyohei Sakaguchi's Zero yen project' at http://www.thememagazine.com/stories/kyohei-sakaguchis-zero-yen-project/ (accessed I9 September 20I2). Sakaguchi's experiments with zero yen living are also documented in art works, books, and collections of photographs, all referenced on his website www.oyenhouse. com/en/index.html.

37 An award winning photo journalist based in Beijing, Shiho Fukada's work can be viewed at http://pulitizercenter.org/project/japan-disposable-worker-laborer. 
of Japanese culture and social practices (of fastidious cleanliness and clear demarcation of formal/informal places. On the inside, however ${ }^{38}$, the bric-a-brac of cooking paraphernalia, radios, blankets, clothes, and furniture arranged in no particular order, squeezed together in an area barely large enough to accommodate a single individual, these dwelling places instantiate similitude rather than resemblance, as resident, 'urban hunter-gatherers' in Sakaguchi's evocative phrase, assemble objects whose use value far outlives their exchange value, instantiating an alternative notion of sustainable living in which the idea of recycling conjoins with community to reformulate notions of property and ownership. Thus in most yoseba and homeless communities, 'thrift shops' sell recycled products, from shoes and blankets to belts and jackets at prices affordable to the people living in these communities.

Conjuring an alternative socio-political imaginary, the suspension of social time within Zero Yen communities is also evident in the erasure of power hierarchies and distinctions that order the socio-political terrain outside. The separation of functional spaces (through shoji or sliding doors), for instance, in traditional Japanese 'mansions' (apartments) that congeal both a matri-centric gender order as well as the fluid and shifting construction of power laden domains of sociality is entirely absent in Zero Yen homes with the blurring of public and private space. Largely absent of women, the everyday practices of cooking, cleaning, washing, typically performed by women in homes across Japan, is overturned here, de-classifying both 'house work' and the gender order within which it is normatively located. Spatialized hierarchies of status and gender in other words are overturned in the heterotopia of Zero Yen communities, making visible the power dynamics enmeshed in regulative ideals of home in Japan. This contrast between the gendered order of idealized notions of 'home' and the freedom from the power hierarchies contained within domestic space in Zero Yen living, forms the basis of Yukihiko Tsutsumi's low budget black-and-white feature film, "My House" about two families in Nagogya. The middle-class family of the Shotas, with the germaphobe mother obsessively cleaning her well proportioned house, in a reversal of the regulative

38 In a startling up close look at those in alternative dwelling abodes, the film maker K.M.Lo engages in conversation with Satoh san inside the latter's tent-home. A row of neatly stacked books alongside a cooking range on which a coffee pot bubbles, a collection of canned food and bottles (too much food, Satoh san remarks) and a framed picture of his parents and children to whom he bids "o yasumi nasai" every night, is telling for the ordinariness of life it speaks of. For Satoh san, this is life as he knows it, and it is good. Contrary to the economistic assumption that those ' in need' need food above all, Satoh san's 'preference rank ordering' of cigarettes, food and beer, speaks to the de-personalizing of 'poverty' that afflicts even the most well meaning developmental discourse on poverty. 
distinctions of home and homelessness, turns out to be the true object of pity for the emptiness and neurosis that corrodes their everyday life. In contrast, the 'homuresu' family of Suzumoto, Sumi-chan and their two friends, although living a life of material hardship appear to be living an ordinary life of shared empathy, community, and self reliance. Because freed from the compulsions of regulative ideals of Japanese society, including its gender order, and the temporal and spatial dislocation that comes with it, the social and working life of the Suzumotos appears to be more desirable, it's encasing in cardboard insulation notwithstanding. Rather than a romanticization of material hardship, however, Tsutsumi seems to be cinematically (re) creating the heterotopic moment contained within the site of homelessness itself ${ }^{39}$.

On yet another register, public parks, like railway platforms, privatized by the cardboard boxes of the homeless, call into question notions of private property that underpin notions of 'home' and community under conditions of capitalism. That parks are public only in the delimited sense that their use is circumscribed to specific activities, designating those associated with dwelling there, illegitimate, is called into question here. Following this line of critique of public and private space, Sakaguchi's construction of a mobile Zero Yen house that "leverages a loophole in Japanese construction law in which a structure on wheels does not count" as a 'house' makes it possible for mobile residences to be set up on 'public' land further undoing settled distinctions between private and public and reinterpreting the concept of property. Referring to the first Zero Yen house he saw on the banks of the Tama River, Sakaguchi reflects, "I realized this man was not 'homeless'... he was the only person in Tokyo who owned a house that he had made entirely himself... They don't have their address. But I don't call them 'homeless.' Because they have a house. I rent a house now and don't have a house. In that sense, I may be a homeless." The inversion of the meaning of ownership and property, where ownership now depends on the deployment of one's own creative labour, and property signifies use not exchange value, stands as a sharp repudiation of the profit-driven calculation of the capitalist exchange economy in general, and the real-estate market in particular which has made private home ownership in Tokyo the most expensive in the world. This reclaiming of a common living place thus calls into question notions of property that underpin Japan's 'capital-nation-state' order, repudiating the myth of Japan and Japanese (nihonjin) as citizens of an unchanging (and undifferentiated) community. Symptomatic of the loss of

39 Yukihiko Tsutsumi has had a long standing critical interest in the condition of the homeless. His I99I film 'Homuresu' precedes 'My House' (2012) by two decades. It is also worth noting that 'My House' is based on Kyohei Sakaguchi's mediations on Zero Yen Living. 
'housing diversity' consequent on the normalization of the private ownership of a single family home or apartment, communities formed around dwelling in Zero Yen homes, offer an oblique and sustained critique of privatization, ownership and property in late capitalist Japan. Finally, the idea of community itself as the locus of ibasho (belonging) firmly centred in Japan around the family, corporation and state, with rigid protocols of inclusion/exclusion and social hierarchies indexed by speech, body posture, and social practices unravels at sites of 'homelessness' only to be re-made in more open ended, nomadic ways. As Zero Yen housing communities are made and re-made on pavements and parks with the periodic dispersion of the homeless by the police, requiring individuals to pack up, move, relocate or return to the same spots to re-make their homes, the borders of the community remain porous, as people move in and out of specific sites. While some residents in San'ya, Kotobuki and Kamagasaki for instance, report living in the area for as much as $15-20$ years, often with day-laborers they have known for as long, others report a far more peripatetic life. Thus, Kawaguchi san, for a time resident in Shinjuku Park, moves to Ueno Park, despite having recourse to 'shelter' in Chiba - many miles from the buzz of city life in Tokyo, to which he repeatedly returns. Alienated from the thick communities of families and the primordial links with furusato (hometowns), communal links forged among residents of Zero Yen homes if not permanent, are no less real.

Within Yoyogi Park in Tokyo, for instance, a community of tent dwellers made up largely of a floating nomadic population of homeless men becomes the magnet for the creation of 'Enoaru Café, the brainchild of artists Misako Ichimura and Tetsuo Ogawa who provide tea, snacks and an opportunity to create art. As word of the 'Homeless Café' spreads, non-resident visitors arrive daily to take part in the life of the Café, abjuring the role of consumer/spectator. Similarly, residents of a homeless village in Nagai Park in Osaka grow vegetables, selling them at bargain prices in the park and at church bringing residents of 'regular' neighbourhoods in contact with those otherwise seen as outsiders to the neighbourhood, obscuring the lines of distinction between 'home owners' and 'home-less,' opening lines of contact and communication between people otherwise contained in domesticated spaces that would ordinarily foreclose these encounters. Likewise, repudiating statist and identitarian logics and their demarcation of public space and order, Take Junichiro's project in the mid 1990 of of painting hundreds of corrugated cardboard houses, home to more than 300 residents in the underground passageway to the West Exit of Shinjuku station in Tokyo, crystallized a notion of a community in movement. As others joined the project of painting houses, and thousands of passers-by 
stopped to look at the painted cardboard facades, encounters between people otherwise hermetically sealed off in distinct social domains, crystallized a fluid and shifting terrain of community, freed from attachments to different identities. The suspicious fire that broke out on 7 February 1998 (killing four people), occasioned the re-assertion of statist order as all homeless occupants were removed allowing the government to proceed with building a moving walkway that prevents any reconstruction of cardboard homes at that site.

Punctuating the time of capital, nation and the state, as well as the archaic time of pre-modern Japan, the temporal dislocation occasioned at what Foucault describes as heterotopic counter-sites enables, in the reading of homelessness developed above, an emergent alternative socio-political imaginary, one that exceeds the limits of the politics of inclusion detailed by social and post-social politics associated with statist and neoliberal imaginaries. In calling attention to the limits of the very terms of home, home-coming, property, and community that structure the socio-political field, homelessness as counter-site offers a productive engagement of inversion and contestation, to delineate a different sociality, one not predicated on a progressivist narrative of futurity, home ownership or shelterization and the violence attendant on the distinctions constitutive of the same. Rather, in drawing attention to the practices of dwelling and endurance demanded by the radical contingencies that shape homelessness as a heterotopic counter-site, the alternative order of the political that emerges here summons homelessness itself as a practice of dwelling, ${ }^{40}$ its emphases on fluidity, open-endedness, and hospitality in the midst of endurance testimony to a political radicality that rebukes the settlements on offer by a compromised 'capital-nation-state' in both its social and post-social guise.

40 The critic Kobayashi Hideo suggested in the I930s that a fundamental feature of contemporary Japanese culture was a pervasive spirit of homelessness and loss, given Japan's internalization of foreign culture. In this context, the project of home-coming may be seen to be predicated on an idea of a stable, authentic and we might, from the vantage point of the late 2000 also say, 'miracle Japan' with its promise of middle class security to all Nihonjin (Japanese). The politics of compassion offers a form of home-coming precisely on these terms. In suggesting, however, that homelessness in Japan may be seen as a practice of dwelling that contains within it the seed of an alternative socio-political imaginary, I have in mind Heidegger's conjoined notions of 'subjectivity as homelessness' as well as his notion of dwelling - buan - as the way in which humans simply are on the earth, as potentially more productive to re-imagining (and constructing) an alternative socio-political order. 


\section{References}

Allison, A., 2009. The Cool Brand, Affective Activism and Japanese Youth. Theory, Culture \& Society 26, 2-3: 89-III.

Allison, A., 20I2. Ordinary Refugees: Social Precarity and Soul in 2I ${ }^{\text {st }}$ century Japan. Anthropological Quarterly 85.2: 345-370.

Amamiya, K. 2007. Purekariato. Dejitaru Hiyatoi Sedai no Fuan na Ikikata (Precariats: The Unstable Way of Life of the Digital Day Labouring Generation). Tokyo: Yosensha.

Aoki, H. 2003. Homelessness in Osaka: Globalisation, Yoseba and Disemployment. Urban Studies 40: 36I-378.

Arai, A.G. 2005. The Neo-liberal Subject of Lack and Potential: Developing "The Frontier Within" and Creating a Reserve Army of Labor in 2I century Japan. Rhizomes ı. Available online http://www.rhizomes.net/issueio/arai.htm (accessed 6 March 20I2).

Arnold, K. 2004. Homelessness, Citizenship and Identity. New York: SUNY Press.

Azuma, H. 2009. Otaku: Japan's Database Animals. Translated by J. E. Abel and S. Kono. Minneapolis: University of Minnesota Press.

Berlant, L. 20II. Cruel Optimism. Durham: Duke University Press.

Biehl, J. 2005. Vita: Life in a Zone of Social Abandonment. Berkeley and Los Angeles: University of California Press.

Binkley, S. 2009. The Work of Neoliberal Governmentality: Temporality and Ethical Substance in the Tale of Two Dads. Foucault Studies 6: 60-78.

Brasor, P. and Tsubuku, M. 20I0. 'New Refuse Rules Criminalize Can-Collecting' Japan Times December 2. http://www.blog/japantimes.co.jp/yen-for-living/newrefuse-rules-criminalize-can-collecting/

Constitution of Japan, Article 25. http://www.kantei.go.jp/foreign/constitution_and_ government_of_japan_constitutione.html

Dehaene, M. and De Cauter, L. (eds). 2008. Heterotopia and the City. London and New York: Routledge.

Dvorak, P. 2003. The Homeless in Japan Find A Place in Cities' Public Parks: Long Economic Slump, Tolerance Allow Shantytowns to Take Root. Wall Street Journal, June $18,2003$.

Eisenstadt. S.N. 1996. Japanese Civilization: A Comparative View Chicago: University of Chicago Press.

Eisenstadt, S. N. (ed.) 2002. Multiple Modernities. New Brunswick, New Jersey: Transaction Publishers.

Ezawa, A. 2002. Japan's "New Homeless." Journal of Social Distress and the Homeless II.4: 279-29I.

Feldman, L.C. 2004 Citizens without Shelter: Homelessness, Democracy, and Political Exclusion. Ithaca: Cornell University

Foucault, M. 1984 [1967]. Of Other Spaces. Heterotopias (J. Miskowiec. Trans.). Architecture/Mouvement/Continuite. http://www.foucult.info/documents/heteroTopia/foucault.heteroTopia.en.html.

Foucault, M. I991. Governmentality in The Foucault Effect: Studies in Governmentality, 
ed. C. Gordon and P. Miller, Chicago, Il.: University of Chicago Press.

Foucault, M. [1976] (1997) Society Must be Defended: Lectures at the College de France 1975-1976 Trans. David Macey. New York: Picador.

Fowler, E. 1996. Sanya blues: Labouring Life in Contemporary Tokyo. New York: Cornell University Press.

Freedman, A. 20II. The Homeless Junior High School Phenomenon: Personalising a Social Problem. Japanese Studies 31.3: 387-403.

Fukada, S. Japan's Disposable Workers. http://pulitizercenter.org/project/japan-disposable-worker-laborer

Genda, Y.2007. Jobless youths and the NEET problem in Japan. Social Science Japan Journal IO.I: 23-40.

Genocchio, B. 1995. Discourse, Discontinuity, Difference: The Question of Other Spaces. In Postmodern Cities and Spaces, edited by S. Watson and K. Gibson, 35-46. Oxford: Blackwell.

Gill, T. 20or. Men of Uncertainty: The Social Organization of Day Labourers in Contemporary Japan. New York: State University of New York Press.

Guzewicz, T.D. 1996. A New Generation of Homeless Hits Tokyo's Streets. Japan Quarterly July-September, 43-53.

Guzewicz, T.D. 2000. Tokyo's Homeless: A City in Denial. New York: Nova Science Publishers, Inc.

Harootunian, H. 200o. History's Disquiet: Modernity, Cultural Practice and the Question of Everyday Life. New York: Columbia University Press.

Harootunian, H. 2005. Some Thoughts on Comparability and the Space-Time Problem. Boundary 2. 32.2: 23-52.

Hasegawa, K. 20or. Saijiki no jikan (Time in Saijiki). In Chikoku no Tanjo: Kindai ni okeru jikan no keisei (The Birth of Tardiness: The Formation of Time Consciousness in Modern Japan, edited by T. Hashimoto and S. Kuriyama, 24I-265. Tokyo: Sangensha.

Hasegawa, M. 2005. Economic Globalization and Homelessness in Japan. American Behavioral Scientist 48.8: 989-1012.

Hasegawa, M. 2006. "We Are Not Garbage!" the Homeless movement in Tokyo, 1994-2002. New York, NY: Routledge.

Hatoyama, Y. 2009. Creating a New Nation. Yukio Hatoyama’s $Y u-A i-$ message from the Prime Minister. Hatoyama cabinet E-mail Magazine November 4.

Hayashi, S. 20II. Representational Discontent. Cultural Anthropology July.

Hetherington, K. 1997. The Badlands of Modernity: Heterotopias and Social Ordering. London: Routledge

Hirayama, Y. (20I0). The Role of Home Ownership in Japan's Aged Society. Journal of Housing and the Built Environment 25: 175-I9I.

Hook, G.D. and T. Hiroko. 2007. "Self-responsibility" and the Nature of the Postwar Japanese State: Risk through the Looking Glass. Journal of Japanese Studies 33.I: 93-I23.

Hook. G.D. and H. Hasegawa (eds.) 200I. The Political Economy of Japanese Globalization London: Routledge.

Iwabuchi, K. 2008. Lost in Translation: Tokyo and the Urban Imaginary in the Era of Globalization. Inter-Asia Cultural Studies 9.4: 543-546. 
Iwata, M. 20Io. New Landscape of Homelessness in Japan: The role of NPOs and Landscape of the Problem. City, Culture and Society I: I27-I34.

Johnson, C. 1982. MITI and the Japanese Miracle: The Growth of Industrial Policy I9251975. Stanford: Stanford University Press.

Karatani, K. 2008. Beyond Capital-Nation-State Rethinking Marxism 20.4: 569-595.

Kennett, P. and Iwata, M. (2003) International Journal of Urban and Regional Research 27.I: $62-74$.

Koseirodosho 2003 (Ministry of Health, Labor, and Welfare). Homuresu no jittai ni kan suru zenkoku chosa hokoku cho. Homuresu no kazu no chosa kekka (Report on the Real Situation of the Homeless Nationwide. The Results of the Census). http:// www.mhlw.go.jp/houdou/2003/03/ho326-5c.html

Koseirodosho 2006. Koseirodosho Hakusho: Jizoku Kanou na Shakai Hoshou Seido to Sasae ai no Junkan - 'Chiiki' Heno Sanka to 'hatarakikata' no Minaoshi (White Paper from the Ministry of Health, Labor and Welfare: Establishing and Supporting a Lasting Social Security System- Checking the 'Regional and 'Work' Support Systems] Tokyo: Kyousei (Ministry of Health, Labor and Welfare).

Kosugi, K. 2008. Escape from Work: Freelancing Youth and the Challenge to Corporate Japan. Melbourne: Trans Pacific press.

Larner, W. 200o. Neoliberalism, Policy, Ideology, Governmentality. Studies in Political Economy 63: 5-25.

Lemke, T. 2002. Foucault, Governmentality, and Critique. Rethinking Marxism I:4964.

Lo. I.M. 20IO. 'Homelessness in Japan', Documentary. Journeyman.tv. http://vod. jouneyman.tv/store? $2010 \mathrm{p}=4459 \&$ s $=$ Homeless + In + Japan

Massey, D. 1992. Politics and Space/Time. New Left Review I/196: 65-84.

Miura, M. 2008. Labor Politics in Japan During the Lost Fifteen Years': From the Politics of Productivity to the Politics of Consumption. Labor History 49.2: I6I-I76.

Miyazaki, H. 2006. Economy of Dreams: Hope in Global Capitalism and its Critiques. Cultural Anthropology 21.2: I47-I72.

Mizushima, H. 2007. Netto Kafue Nanmin to Hinkon Nippon (Net café refugees and poverty in Japan). Tokyo: Nihon Terebi Hoso Kabushiki Kaisha.

Mizuuchi, T. 2003. The Growth in the Number of People Sleeping Rough in the City of Osaka, Japan. Urban Culture Research I: 20-36.

Mori, Y. 2005. Culture = Politics: The Emergence of New Cultural Forms of Protest in the Age of Freeter. Inter-Asia Cultural Studies 6.1:17-29.

OECD FactBook Statistics 20II-20I2. http://www.oecd-ilibrary.org/economics/oecdfactbook-20II-20I2-factbook-20II-en

Ogawa, A. 2009. The Failure of Civil Society: The Third Sector in Contemporary Japan. New York: SUNY Press.

Ong, A. 2006. Neoliberalism as Exception: Mutations in Citizenship and Sovereignty. Durham, N.C.: Duke University Press.

Poverty Rate Hit Record High in 'o9. Japan Times Online I3 July 2011.

Povinelli, E. A.20Ir. Economies of Abandonment: Social Belonging and Endurance in Late Liberalism. Durham and London: Duke University Press.

Public Housing on the Ropes http://catforhead.wordpress.com/20Io/I2/o8/publichousing-on-the-ropes/ 
Rose, N. 1996. Refiguring the Territory of Government. Economy and Society 25: 327356.

Sakaguchi, K. 20I2. Zero Publics- Practice for Revolution. Exhibition. http://www. berlinerfestspiele.de/en/aktuell/festivals/foreign_affairs/program_fa/pro

Sakaguchi, K. Zero Yen Project. http://www.thememagazine.com/stories/kyohei-sakaguchis-zero-yen-project/

Sakaguchi, K. Web-Site. www.oyenhouse.com/en/index.html.

Saldanha, A. 2008. Heterotopia and Structuralism. Environment and Planning A 40: 2080-2096.

Sand, J. 2003. House and home in modern Japan. Boston: Harvard University Press.

Shinoda, T. 2009. Which Side Are You On? Hakenmura and the Working Poor as a Tipping Point in Japanese Labor Politics. The Asia-Pacific Journal April 4.

Soja, E. 1995. Heterotopologies: A Remembrance of Other Spaces in the Citadel-LA. In Postmodern Cities and Spaces, edited by S. Watson and K. Gibson, 13-34. Oxford: Blackwell.

Steger, B. 2006. Sleeping Through Class to Success: Japanese Notions of Time and Diligence. Time and Society I5: 197-2I4.

Tachibanaki, T. 2008. Introdakushyon - kakusakara hinkonhe (Introduction - from difference to poverty). In Kakusa to hinkon: 20 ko (Difference and Poverty 20 cases), edited by T. Makino and E. Murakami, 8-18. Tokyo: Akashi Shoten.

Tamamoto, M. 2009. Japan's Crisis of Mind. The New York Times. March 2.

Tanaka, S. 2004. New Times in Modern Japan. Princeton: Princeton University Press.

The new homeless law. Act to Provide Special Measures for the Support of the Self Reliance of the Homeless (Homuresu no jiritsu shien to ni kan suru tokubetsu sochi ho). http://www.homepage3.nifty.com/shelter-less/English/eng_idx.html.

Tsuji, Y. 2006. Railway Time and Rubber Time: The Paradox in the Japanese Conception of Time. Time \& Society I5: 177-194.

Tsutsumi, Y. 1991. Homuresu. Film.

Tsutsumi, Y. 20I2. My House. Film.

Vij, R. 20I2. Temporality, Civic Engagement and Alterity: Indo-kei in Contemporary Japan. Alternatives 37.I: 3-29.

Walker, R.B.J. 1998. Both Globalization and Sovereignty: Reimagining the Political. Paper Delivered at the University of Wales, Aberystwyth, the University of Oslo, and Western Washington.

Watson, S. and Gibson, K. (eds.) I995. Postmodern Cities and Spaces. Oxford: Blackwell. Yoda, T. 200o. The Rise and Fall of Maternal Society: Gender, Labor, and Capital in Contemporary Japan. The South Atlantic Quarterly 99.4: 865-902.

Yoshida, M. 20I2. The "Hidden Homeless" in Japan's Contemporary Mobile Culture. http://www.neme.org/1500/hidden-homeless (Accessed 30 October 2012).

Yuasa, M. 2008. Hanhinkon: "Suberridaishakkai" kara no dasshutsu (Reverse Poverty: Escape from a Sliding Down Society”). Tokyo: Iwanami Shinsho. 